\title{
Presidents and Ideologies: A Transitivity analysis of Bingu wa Mutharika's inaugural address
}

\author{
Wellman Kondowe \\ Department of Languages and Literature, Mzuzu University, Malawi, C. Africa
}

Email address:

welkondowe@yahoo.com

\section{To cite this article:}

Wellman Kondowe. Presidents and Ideologies: A Transitivity Analysis of Bingu wa Mutharika's Inaugural Address. International Journal of Language and Linguistics. Vol. 2, No. 3, 2014, pp. 174-180. doi: 10.11648/j.ijl1.20140203.16

\begin{abstract}
The study is set to analyse how the third Malawian president Bingu wa Mutharika manipulated language in his second inaugural address to enhance his political ideologies by using Halliday's transitivity system as a theoretical framework. Among the six processes outlined in the framework, the study discovers that material processes highly dominate the speech, distantly followed by relational, while verbal processes come third. Material clauses suggest that Bingu construes the world in terms of his past and future happenings by commemorating his first term achievements and setting his administrative and political principles of his next tenure. His choice of actors suggests that Bingu attributes the achievements to himself which is a characteristic of undemocratic leadership style. He also uses a majority of relational identifications to point out to himself and his administration as the main development players. Verbal processes have been used as markers of transition and topic shift; still, he refers to himself as the main sayer. The speech foregrounds Bingu as a leader with autocratic and dictatorship leadership ideologies. The study concludes that such leadership characteristics could be possible reasons that led to his political downfall as his record on good governance, human rights, and political tolerance significantly got worsened in his second term.
\end{abstract}

Keywords: Bingu wa Mutharika, Malawi, Systemic Functional Grammar, Transitivity, Inaugural Address, Political Ideologies

\section{Introduction}

Language is a heavily loaded vehicle. Our words are never neutral, transparent or innocent. They always carry the power and ideologies that reflect the interests of those who speak or write them (Taiwo 2007). As language users, we have several words at our disposal to choose from when producing a text; the choice of certain words over others may reflect conscious and unconscious ideologies held by those who produce them. At the same time they may shape the meanings of a text towards certain preferred ideologies. Therefore, as observed by van Dijk (2006), the analysis of language is a critical component in discovering and understanding particular ideologies. Van Dijk (2006), uses the term ideology to refer to attitudes, set of beliefs, values and doctrines with reference to religious, political, social and economic life, which shape the individual's and group's perception and through which reality is constructed and interpreted.

Many studies have been conducted to analyze political discourse especially with reference to countries' presidents (Horváth 2009; Duran 2008; Green 2007; Opeibi 2005).
Scholars have realized that Presidents stand for their countries. They have also come to be viewed as common fathers of their citizens, burdened with the care of their children (Hinckley, 1990). They have become people's representatives; hence, they should speak for their people. The voice of the President is taken as the voice of the people. The political ideologies embodied in presidential speeches and addresses, therefore, reflect the political ideologies and realities of their nations.

In many democratic countries, it has become a de facto requirement for the president-elect to deliver an address on inauguration ceremonies. The address is an anticipated feature of all inaugural ceremonies (Rossiter, 1960). It is an essential element in a ritual of transition in which the covenant between the citizenry and their leaders is renewed. It is where the newly elected president outlines, among other things, his perspective on the manner, conduct and overall form of his government. The speech shapes the way in which the people understand the system of government on both theoretical and functional levels. The address is a form of rhetoric where the president commemorates the nation's 
past, envisions the future, and tries to set the tone for the next years in office while focusing on the present (Sigelman, 1996). The current study aims at analyzing the inaugural address of the third Malawian President Bingu wa Mutharika's second term in office.

\subsection{Bingu wa Mutharika and his Presidency}

Bingu wa Mutharika (hereinafter referred to as 'Bingu') came into power in 2004 after a long and active early career in both Malawian and International politics. In Malawi, Bingu was one of the first founding members of United Democratic Front (UDF), a party which ushered him into power in 2004 general elections after all attempts to re-usher Bakili Muluzi (his predecessor) through an Open Term Bill proved futile (Green, 2008). UDF supporters then rallied behind Bingu as their UDF torch bearer in the 2004 national elections, a move that made him become the third president of the Republic of Malawi.

As soon as he was sworn in as president of Malawi on 24 May 2004, Bingu set out policies to combat corruption and improve the government's economic policies ${ }^{1}$. Investigations started against several prominent UDF officials, and many were arrested. International donors were impressed with his policies and re-initiated the flow of aid, which had been stopped over claims of Muluzi's financial mismanagement (Green, 2008). By the end of his first year in office, political infighting against ex-President Muluzi's camp forced Bingu to quit the UDF party and formed his own, Democratic Progressive Party (DPP). Several UDF MPs followed him, a move that worsened the hatred with the Muluzi's camp. In June 2005, Bingu was placed under an impeachment motion by the UDF in the National Assembly (Ntata, 2012). The parliamentary meeting was so tense. In many National budget assemblies, the UDF and MCP prioritized the implementation of Section 65 of the Malawi constitution before the budget got tabled. This section of the Malawian constitution empowers the speaker of the National Assembly to declare vacant seats of those parliamentarians who have crossed the flow in the parliament. This was a blatant move to frustrate Bingu's government as it could not operate without MPs. This posed a great threat to his administration and the success of his presidency.

However, Bingu had an overwhelming support from all walks of life in the nation and he emerged a winner, for the second time, on the fourth Presidential and parliamentary elections held on $19^{\text {th }}$ May 2009, having defeated six political parties with a very wide margin with a total of $2,963,820$ votes $(66 \%)$ (EISA, 2009). Some analysts suggested that this election marked a departure from Malawi's traditional voting patterns, which were heavily influenced by region (EISA, 2009). Bingu and Joyce Banda were respectively sworn in as President and Vice-President on 22 May 2009 at Kamuzu stadium in Southern city of Blantyre. Therefore, as a president elect, he was expected to give an address which this study seeks to analyze. The

\footnotetext{
${ }^{1}$ Source: www.africanhistory.about.com
}

speech has been chosen because it is the most recent inauguration address of the Malawian president-elect, which periodically comes at five-year interval. Furthermore, being his second inauguration, it is hoped that this speech would give a good summary of the political and economic state of the nation.

\section{Theoretical Framework}

The study employs M.A.K Halliday's Systemic Functional Grammar (SFG) as its theoretical framework. SFG is called systemic because it is established that individuals have alternative choices available for them to produce linguistic utterances and texts. The system is what integrates the notion of choice in language through grammar which is the system network. The grammar offers language users a variety of options and choices. The theory is called functional because of the variety of purposes language is used for (Halliday, 1994). The function of language is to make meaning, and these meanings are influenced by the social and cultural context in which they are exchanged, and that the processes of using language is semiotic: a process of making meanings by choosing.

Halliday postulates that language is a multi-strata system. It starts out in the extra-linguistic realm of the social context of situation called register, with its three variables of field, tenor, and mode. It then goes through the intra-linguistic strata of semantics. This is where meaning is realized in three components: ideational, interpersonal, and textual. Then it comes in form and wording in the lexico-grammar with its meta-functional related systems of transitivity, mood and modality, and theme.

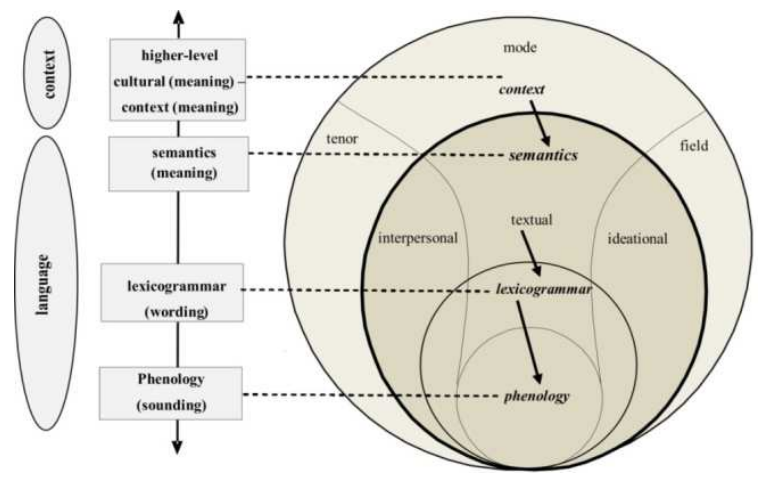

Fig 1. Language as a stratified system network (from Patpong, 2009:197)

According to Halliday (1994), language mainly serves three main functions which he refers to as three metafunctions the ideational metafunction, concerned with the representation of reality; the interpersonal metafunction, concerned with establishing and maintaining the interaction between the speaker and the hearer; and the textual metafunction, concerned with presentation of ideational and interpersonal meanings as text. The three metafunctions in turn give rise to three strands of meaning in a clause i) clause as representation, ii) clause as exchange, and iii) clause as message (Wang, 2008:58). However, this study mainly 
focuses on how meaning of Bingu's speech is represented and realized in the transitivity grammar of the clause, which is the crucial component in ideational metafunction.

\subsection{Transitivity System}

The main argument of the transitivity system is that our most powerful conception of reality consists of "goings-on" of doing, happening, feeling, being. These goings-on are sorted out in the semantic system of the language, and expressed through the grammar of the clause (Halliday, 1994). The clause is, therefore, analysed for its potential to represent both the outer and the inner world of human beings. The representation of reality is achieved by means of a set of processes along with their participants and the circumstances in which they unfold (Filho, 2004). It expresses what's happening, what's being done, what is felt and in what state it is (Cheng Yumin, 2007). The transitivity system includes six processes: material, mental, relational, behavioral, verbal, and existential. The term 'process' is used here in an extended sense to cover all phenomena and anything that is expressed by a verb; this can be an event, whether physical or not, state, or relation.

\subsubsection{Material Processes}

Material processes are processes of doing in the physical world. They have two inherent participants involved in them. The first is the Actor, which is an obligatory element and expresses the doer of the process (Halliday \& Matthiessen, 2004). The second is the Goal, which is an optional element and expresses the person or entity whether animate or inanimate affected by the process.

\subsubsection{Relational Processes}

Relational processes are concerned with the process of being in the world of abstract relations (Thompson, 2004). Normally, an abstract relationship that exists between two participants associated with the process is considered, but unlike the case of material process, a participant does not affect the other participant in a physical sense.

Relational processes can be classified into two types: Attributive and Identifying (Thompson, 2004). Attributive relational process expresses what attributes a certain object has. This type of relational process basically suggests the relationship of ' $x$ carries the attribute $y$,' where an attributive adjective is assigned to a participant, the carrier. The relationship between the attribute and the carrier is commonly expressed by the verb $b e$. The identifying relational process expresses the identical properties of two entities. This process contains two independent participants: a Token that is a holder or an occupant that stands to be defined, and a Value that defines the token by giving it meaning, referent, function, status, or role (Halliday, 1994).

\subsubsection{Mental Processes}

Mental processes encode the meanings of feeling or thinking. They are internalized processes, in contrast to the externalized processes of doing and speaking. Halliday and Matthiessen (2004) observe that, unlike material processes, mental processes always involve at least one human participant who has the mind in which the process occurs. The participant involved in the mental process is known as Senser. The Phenomenon is the entity which is felt, thought, or perceived by the sensor.

\subsubsection{Verbal Process}

A verbal process is the process of saying, and it exists on the borderline between mental and relational processes. Just like saying and meaning, the verbal process expresses the relationship between ideas constructed in human consciousness and the ideas enacted in the form of language (Thompson, 2004). The participant who is speaking is called Sayer, the addressee to whom the process is directed is Target, and what is said is Verbiage.

\subsubsection{Existential Processes}

They represent processes of existing and happening. Existential sentences typically have the verb be, and the word there is necessary as a Subject although it has no representational function (Halliday \& Matthiessen, 2004). The object or event that is being said to exist is called Existent. An Existent can be any kind of phenomenon, such as a thing, person, object, institution or abstraction, action, or event.

\subsubsection{Behavioral Processes}

Behavioral processes are processes of physiological and psychological behavior. They are the least salient of six process types, and the boundaries of behavioral processes are indefinite, they are partly material and partly mental (Halliday \& Matthiessen, 2004). Behavioral processes represent outer manifestations of inner workings, the acting out of processes of consciousness and physiological states. The participant who is behaving is called Behaver.

\section{Data Analysis}

The transitivity analysis of processes, participants followed the following three steps: (1) the text was parsed into its constituents clauses, (2) processes were then isolated, and we determined which participant is doing each process; finally (3) we determined what sorts of processes they are, and which participant is engaged in which type of process. A discussion focuses on the first three most frequent process types as they are statistically distributed in the introduction, the main body, and the conclusion of the address.

\section{Results and Discussion}

As the study of the speech proves, contrary to Herriman's (2000a) (cited in Wang, 2008) the majority of the clauses, identified in this study, are material, followed by relational, and verbal in that order, as shown in the Table 1 below. 
Table 1. Distribution of Process and their types

\begin{tabular}{cccccccccccccc}
\hline \multirow{2}{*}{$\begin{array}{c}\text { Speech } \\
\text { sections }\end{array}$} & \multicolumn{2}{c}{ Mat. } & \multicolumn{2}{c}{ Rel. } & \multicolumn{2}{c}{ Ver } & \multicolumn{2}{c}{ Process Type } & \multicolumn{2}{c}{ Mental } & \multicolumn{2}{c}{ Exist. } & \multicolumn{2}{c}{ Behav. } & Total \\
& No. & Freq & No. & Freq & No. & Freq. & No. & Freq & No. & Freq & No. & Fre & $02 \%$ \\
\hline Intro. & 82 & $64 \%$ & 30 & $23 \%$ & 04 & $03 \%$ & 08 & $06 \%$ & 02 & $02 \%$ & 02 & $02 \%$ & 128 \\
Body & 141 & $74 \%$ & 29 & $15 \%$ & 11 & $05 \%$ & 06 & $04 \%$ & 03 & $02 \%$ & - & - & 190 \\
Concl. & 27 & $53 \%$ & 06 & $12 \%$ & 11 & $22 \%$ & 05 & $10 \%$ & 01 & $02 \%$ & 01 & $02 \%$ & 51 \\
Total & 250 & $68 \%$ & 65 & $18 \%$ & 26 & $07 \%$ & 19 & $05 \%$ & 6 & $02 \%$ & 03 & $01 \%$ & 369 \\
\hline
\end{tabular}

Transitivity analysis of the speech has discovered a total of 369 clauses, as indicated in Table 1. Material processes take a lion's share accounting for $64 \%, 74 \%$, and $53 \%$ of all the clauses found in introduction, main body, and in the concluding paragraphs. Relational clauses come a distant second with a total of $65(18 \%)$, with a distribution of $23 \%$ in introductory paragraphs, $15 \%$ in the main body, and $12 \%$ in conclusion. Verbal and Mental clauses have an overall representation of $07 \%$ and $05 \%$ respectively, throughout the three speech sections. The occurrence of existential and behavioral clauses is very insignificant, with $02 \%$ and $01 \%$ respectively.

\subsection{Material Processes}

The preponderance of material clauses realized in the speech, suggest that Bingu construe the world more in terms of actions of his past and future happenings. In the introductory paragraphs, he uses material processes to comment on his previous government by stating some achievements and challenges he encountered in his first term of office, and to appreciate the role different stakeholders played in his first term and during the just ended elections. Most processes in the introduction also serve to unify the audience and the nation that was recently torn apart during the campaign period (Sigelman, 1996) and, finally, to restore people's confidence for the second opportunity to rule the nation. Consider instances below:

1. $\quad<30 \mathrm{a}>$ I had made several pledges and commitments $<30$ b $>$ to fight poverty $<30 \mathrm{c}>$ and take Malawi on the path to prosperity.

2. $<35 \mathrm{~b}>$ that our nation will produce enough food $<35 \mathrm{c}>$ to feed themselves

3. $<36 \mathrm{~b}>$ that I would turn Malawi into a "hunger-free" nation

4. $<47 \mathrm{a}>$ I had pledged to fight the HIV/AIDS pandemic

The above examples indicate that Bingu utilizes material clauses, at the onset of his speech, to celebrate his first achievements in office by listing some of developmental activities he had implemented as a means in restoring people's confidence both locally and internationally.

One of his major achievements witnessed during his era was his fight against hunger. Hunger has, for ages, been identified as an enemy of the State, a phenomenon which is also recognized in the National Anthem. Bingu introduced Farm Input Subsidy Program (FISP) especially on fertilizer, the idea which international major forex controlling institutions like IMF and World Bank stood against (Ntata, 2012). Juma (2011:02) further notes that
Malawi's remarkable efforts to address the challenges of food security were implemented against the rulebook of economic dogma that preaches against agricultural subsidies to farmers. Malawi's President Bingu wa Mutharika defied these teachings and put in place a series of policy measures that addressed agricultural development and overall economic development. He serves as an example for other African leaders of how aggressive agricultural investment ( $16 \%$ of government spending) can yield increased production and results.

Due to his impressive performance, Bingu received nicknames and titles from local political commentors ${ }^{2}$, while internationally, he received several honorary degrees and awards ${ }^{3}$.

In the main body of the address, Bingu uses material processes to set out his political and economic principles that would govern the new administration by demonstrating what the government has achieved, what they are doing, and what they would do in different aspects of affair. Through the processes of doings and actions, he affirms his commitment to values the nation has pursued so far by creating a sense of continuity between the glories of the past and the challenges of the present, and to reassure his audience, in the words of Korzi (2004) that the transition to the new tenure in office does not pose any threat to the nation's historic legacy. See the following pair of clauses in Table 2:

Table 2. Paired material clauses that carry a sense of progression

\begin{tabular}{cclll}
\hline $\begin{array}{c}\text { Example } \\
\text { No }\end{array}$ & $\begin{array}{c}\text { Clause } \\
\text { No }\end{array}$ & \multicolumn{1}{c}{ Actor } & Process & \multicolumn{1}{c}{ goal } \\
\hline \multirow{2}{*}{5} & $<68 \mathrm{a}>$ & $\begin{array}{l}\text { My } \\
\text { administration }\end{array}$ & $\begin{array}{l}\text { implemented } \\
\text { will continue }\end{array}$ & $\begin{array}{l}\text { agricultural } \\
\text { reforms }\end{array}$ \\
& $<77>$ & $\begin{array}{l}\text { My } \\
\text { government } \\
\text { to prioritize }\end{array}$ & $\begin{array}{l}\text { agriculture } \\
\text { on } \\
\text { vocational } \\
\text { skill training } \\
\text { particular }\end{array}$ \\
\hline
\end{tabular}

${ }^{2}$ Firstly, he was nicknamed chitsulo cha njanji ('an iron rail') to depict his strong character for standing against local and foreign pressure to achieve what he intended. Secondly, Mose wa lero ('The modern Moses') a biblical allusion to Moses who delivered the Israelites out of the bondage from Egypt to Canan. He was then titled Ngwazi ('The conqueror') to show that he had conquered hunger.

${ }^{3}$ In April 2010, he was titled Professor of Economics by East China Normal University. He was honored Doctor of Letters (D.Lilkmktt) Degree Honoris Causa by the University of Delhi in October, 2010. In 2005, he received an honorary Doctor of Philosophy (PhD) Degree (Honoris Causa) by University of Strathclyde in Scotland (Malawi Voice, 2012). Until his death Bingu was being referred to as 'Ngwazi Professor Bingu wa Mutharika'. 


\begin{tabular}{|c|c|c|c|c|}
\hline $\begin{array}{c}\text { Example } \\
\text { No } \\
\end{array}$ & $\begin{array}{c}\text { Clause } \\
\text { No } \\
\end{array}$ & Actor & Process & goal \\
\hline \multirow{3}{*}{7} & & government & to pay & $\begin{array}{l}\text { attention to } \\
\text { skill building }\end{array}$ \\
\hline & $<142 b>$ & $\begin{array}{l}\text { My } \\
\text { government }\end{array}$ & prioritized & irrigation \\
\hline & $<144>$ & $\begin{array}{l}\text { My } \\
\text { government }\end{array}$ & $\begin{array}{l}\text { will continue } \\
\text { to give }\end{array}$ & $\begin{array}{l}\text { irrigation a } \\
\text { priority }\end{array}$ \\
\hline
\end{tabular}

As he addresses the nation, as noted in the examples (5-7) in Table 2, Bingu assures Malawians that his administrative policies, witnessed in the first tenure, will continue. He, therefore, looks at the inauguration merely as a point of progression and not a point of change evident in his choice of process will continue, which marks progression. Furthermore, knowing that inauguration often brings a change in many nation states worldwide usually leading to crisis, instability and revolutions which started during the campaign period (Sigelman, 1996), there is great need that the president should give such an assurance.

\subsubsection{Choice of Actors in the Clauses}

The study also examines nominal groups that have been assigned acting roles in various material clauses of the speech. It is believed that a closer examination of actors and their roles is also ideologically motivated. The analysis discovers seven main actors, namely: I, we, my government/my administration, they, Malawi, you, people of Malawi/Malawians. However, some of the clauses are discovered to be agentless. Such clauses are not given any attention in the discussion.

The analysis of actor indicates that pronoun we top in the majority of material clauses with a representation of $37 \%$ of the total 250 material clauses, seconded by $I$ with $18 \%$. Nominal phrases my government/my administration have a $12 \%$ representation in the speech. Other material clauses have a variety of actors as noted in Table 3 below. Actor $I$ comes first in the introduction and we comes second with $39 \%$ and $24 \%$ respectively. However, we has by far dominated in the majority of material clauses in the main body with $43 \%$. In concluding paragraphs, $I$ and we have a relative equal representation of $40 \%$ and $48 \%$ respectively. The statistical distribution of actors in Table 3 reveals that Bingu identifies himself and his administration as main actors and sole doers of main processes. Actor we followed by $I$ have dominated the majority of main clauses in the material world. Pronoun we which has traditionally been associated with inclusiveness, (Halliday, 1994 and Thompson, 2004), is anaphorically employed in the speech to represent him and his administration.

Table 3. Statistical distribution of actors

\begin{tabular}{|c|c|c|c|c|c|c|c|c|c|c|c|}
\hline & & & \multicolumn{9}{|c|}{ Actors } \\
\hline & & I & We & $\begin{array}{c}\text { My Gvt My } \\
\text { admn }\end{array}$ & They & Malawi & You & $\begin{array}{c}\text { People of } \\
\text { Malawi }\end{array}$ & others & agentless & Total \\
\hline \multirow{2}{*}{ Intro. } & No & 32 & 20 & 05 & 02 & 03 & 02 & 02 & 07 & 09 & 82 \\
\hline & Freq & $39 \%$ & $24 \%$ & $06 \%$ & $02 \%$ & $04 \%$ & $02 \%$ & $02 \%$ & $09 \%$ & $11 \%$ & \\
\hline \multirow{2}{*}{ Body } & No. & 02 & 61 & 24 & 04 & 09 & - & 02 & 22 & 17 & 141 \\
\hline & Freq & $01 \%$ & $43 \%$ & $17 \%$ & $03 \%$ & $06 \%$ & - & $01 \%$ & $16 \%$ & $12 \%$ & \\
\hline \multirow{2}{*}{ Conc } & No. & 11 & 13 & - & - & - & 01 & & 01 & 01 & 27 \\
\hline & Freq. & $40 \%$ & $48 \%$ & - & - & - & $04 \%$ & - & 04 & $04 \%$ & \\
\hline Total & & $18 \%$ & $37 \%$ & $12 \%$ & $02 \%$ & $05 \%$ & $01 \%$ & $02 \%$ & $12 \%$ & $11 \%$ & 250 \\
\hline
\end{tabular}

The speech gives out the impression that Bingu has healed the nation under peril and has turned stone into bread by attributing the past achievements to him and his administration. The address excludes citizenry in the aforesaid achievements acting contrary to ideal democratic principles of creating government of the people for the people and by the people. Just like Duran's (2008) study on Senator John Kerry would reveal, Bingu similarly portrays himself as an active participant, a candidate of actions who cherishes his own values and would continue to be guided by them. By assuring the masses that he has the sole responsibility of developing the nation and that he would continue operating with a solo government, he foregrounds himself as a leader with autocratic ideological principles.

\subsection{Relational Clauses}

The analysis further discovers that Bingu evenly distributed attributive and identification clauses in the introductory part, but hugely preferred identifications in the main body, taking over $70 \%$ of all relational clauses identified to provide definitions and explanations of who he is, and the current political and economic state of the nation . $\mathrm{He}$, therefore, renders himself an interpreter of the current situation that assigns attributes to the participants involved. Just like Obama's speech, as observed by Wang (2010), Bingu chooses processes of being as an appropriate way to explain the complex relationship between some abstract items because they sound definite. These processes elaborate the relationship between ideals and speaker's beliefs which can reach their aim of making the reasoning naturally and unconsciously accepted by the audience. 
Table 4. Examples of relational clauses

\begin{tabular}{ll}
\hline Attributives & Identifications \\
\hline $\begin{array}{l}\text { I am happy (four times). } \\
\text { Malawi is not a poor country. }\end{array}$ & Your presence is a source of inspiration. \\
$\begin{array}{l}\text { Malawi has had huge food supplies. } \\
\text { We have a proven record. }\end{array}$ & Corruption is a menace in our society. \\
Many youth have a future of hope. & Malawi is able to feed people. \\
$\begin{array}{l}\text { People have access to electricity. } \\
\text { Civil servants have had } 300 \% \text { salary increment. }\end{array}$ & Education, Science and Technology are lynchpins of any national socio-economic development. \\
\hline
\end{tabular}

As he opens his speech, he takes a good time to describe a number of entities related to his election. For instance, he describes himself, the elections and the electoral process, Malawi, DPP leaders, the youth, the elderly, and civil servants, just to cite a few.

$\mathrm{He}$ also outlines a number of visible entities that the nation and the people posses at the moment of utterance as development indicators using a variety of possessive attributive relational clauses. These clauses have been signaled by main verbs have and has to indicate possession. For instance: Malawi has 1) huge food supplies, 2) a super hamper harvest. The people have 1) a future of hope, 2) access to fertilizer, 3) a guaranteed social support, and 4) over $300 \%$ salary increment. Being the main player in the development, as observed above, these could be possible reasons he describes himself as a very happy (four times) and a grateful person for being given a second change to govern the nation. The ideological standpoint of 'Malawi on the right path to prosperity' is strengthened here. Furthermore, he blatantly chooses identifications with positive values to create good impression to the citizenry and solidify his image as an expert and strengthen his political morale.

\subsection{Verbal Processes}

Unlike other political discourse studies that have recognized mental processes to be the third in rank for their potential of arousing audience emotions, this analysis discovers that verbal processes are highly employed than mental processes. Bingu often refers to himself as a direct sayer of verbal processes using pronoun $I$. The analysis indicates that there are very few clauses which have been said by 'others' as Table 5 indicates. This further extends Bingu's exclusive politics. He takes advantage of these processes to express his inner most feeling towards his victory.

Table 5. Examples of verbal processes identified in the address

\begin{tabular}{llll}
\hline \multicolumn{1}{c}{ Sayer } & \multicolumn{1}{c}{ Process } & \multicolumn{1}{c}{ target } & \multicolumn{1}{c}{ verbiage } \\
\hline & $\begin{array}{l}\text { thank } \\
\text { appeal } \\
\text { wish to express } \\
\text { say/said/must say } \\
\text { wish to talk } \\
\text { wish to conclude }\end{array}$ & $\begin{array}{l}\text { you all } \\
\text { to you } \\
\text { to the people of } \\
\text { Malawi }\end{array}$ & $\begin{array}{l}\text { my sincere } \\
\text { appreciation }\end{array}$ \\
$\begin{array}{l}\text { Work of } \\
\text { my hands } \\
\begin{array}{l}\text { People of } \\
\text { Malawi }\end{array}\end{array}$ & have spoken & about corruption \\
\hline
\end{tabular}

Bingu uses verbal processes for a number of reasons: to thank, express his appreciation and appeal to the people. He also uses the processes to mark a shift in topic. For instance, I wish to talk about corruption, and I wish to conclude are direct signaling devices of topic shift. They have been so useful in holding the speech together and his audience all along. Verbal clauses have also been used to emphasize his commitments and stress his propositions, for instance, I said, I must say. These clauses are meant to capture the attention of audience as he makes his address. He postulates himself as a man of his words and an agent of change that should be trusted and people should have confidence in. The processes also concretize what could otherwise be viewed as abstract activities in making them appear more vivid by appealing to audience sense of hearing. He dedicates his land slide victory to the voice of the people [who] have spoken unanimously through the ballot. While he continues to mention himself as the main sayer of the main verbal clauses, in the concluding paragraphs, he uses the clauses such as $I$ reiterate, and $I$ want to assure you as emphasis markers, hinting on major points he wishes his audience to remember, while assuring his commitment of the aforesaid promises.

\section{Summary and Conclusions}

Results of the study indicate that material processes by far dominate the address, in all the three sections, distantly followed by relational clauses. Verbal clauses come third. Pronoun we has been the major actor of the address, while $I$ comes second. Material clauses suggest that Bingu construes the world in terms of his past and future happenings basically by commemorating his first term achievements and setting his administrative and political principles of his next tenure. In the address, he celebrates his achievements for making Malawi a hunger free nation, for fighting corruption, and for stabilizing economy, amongst others. However, the speech indicates that he never attributes the same to anyone. He continuously identifies himself and his administration as the main development players. The address shows autocratic and individualistic leadership trails.

In relational clauses, Bingu is portrayed as an interpreter of current Malawian situation that assigns attributes to the participants involved by tactically choosing identifications of positive values to create good impression to the citizens and solidify his political image. Verbal processes have been used as markers of transition and topic shift, which have been very successful in binding the speech and holding the 
audience throughout the address. Still, he refers to himself as the main sayer of the processes.

The transitivity analysis of the address has been so instrumental because it clearly presents Bingu's political ideologies that were so hidden in his first term but were heavily loaded in his inaugural speech and came into fruition in his second term. Despite having successfully served Malawi in his first term, his political image dramatically got worsened both locally and internationally at the helm of his second term. His record on good governance, human rights, and political tolerance significantly got worsened, and citizenry wrath towards him grew stronger ${ }^{4}$

The study observes that Bingu lost popularity in his second term because he became autocratic and dictatorial, traits which are first linguistically manifested in his second inaugural. Just like his choice of processes, participants, personal pronouns, have shown, Bingu foregrounds himself as the sole prayer of the development initiatives that happened in the country. His decisions suddenly started becoming heavily undemocractic and unbearable to the masses, a character that was highly protested against eventually leading to his downfall.

Future analysts can also compare the inaugural address and State of the Nation addresses of 24th May 2010 and 23rd May 2011 titled 'Building National Capacity for Sustainable Growth and Development' and 'A Promise Delivered' respectively. These addresses are essential because they will show how Bingu presented himself at the crux of second term.

\section{References}

[1] Cheng Yumin, (2007) An Analysis of Style Features of Inaugural Speeches given by American Presidents based on the Functional Theory of Halliday. MA Thesis. Tai Yuan Science University.

[2] Duran, J. M. (2008) The Analysis of Political Discourse Applied to Bush's and Kerry's Speeches. Systemic Functional Linguistics in Use. Odense working papers in Language and Communication. 29: 267-282.

[3] EISA (2009) The Malawi Presidential and Parliamentary Elections of 19 May 2009. Johannesburg: EISA 14 Park Rd. Richmond.

[4] Filho, P.H.L.P. (2004) Systemic Functional Grammar: A tool to Investigate the Lexicogrammatical Complexification of Advanced Portuguese-EFL Interlanguage. Retrieved from: https://periodicos.ufsc.br/index.php/desterro/article/view/74 05 on 25 th June, 2012.

[5] Green, C. (2007) Discursive Strategies in Political Speech: The words of Dr. Bingu wa Mutharika. Journal of Political

\footnotetext{
${ }^{4}$ Some news headlines that appeared in the local leading newspapers The Nation, and Daily Times: H1. GOVT HAS LOST DIRECTION The Nation, April 21, 2011 H2. Bishop Zuza denounces dictatorship Daily Times, August 17, 2011 H3. Bingu labels critics stupid Daily Times, May 19, 2011
}

Discourse Analysis 20072 (1): 59-74.

[6] Halliday, M. A. K., and Matthiessen, C. (2004) An Introduction to Functional Grammar. Beijing: Foreign Language Teaching and Research Press.

[7] Halliday, M.A.K. (1994) An Introduction to Functional Grammar. London: Edward Arnold.

[8] Hinckley, B. (1990) The Symbolic Presidency: How Presidents Portray Themselves. New York: Routledge.

[9] Horváth, J. (2009) Critical Discourse Analysis of Obama‘s Political Discourse. Language, Literature and Culture in a Changing Translatlantic World. International Conference Proceedings.

[10] Juma, C. (2011) The New Harvest: Agricultural Innovations in Africa. Oxford: Oxford University Press.

[11] Korzi, M. (2004) The President and The Public: Inaugural Address in American History. Congress and the Presidency. 31(1): $21-52$

[12] Mutharika, B. w. (2009, May) The Work of My Hands Speaks for me. Retrieved from: http://www.malawi.gov.mw/ on March, 22, 2012.

[13] Ntata, A. (2012) Trappings of Power: Political Leadership in Africa. UK: AuthorHouse.

[14] Opeibi,T. (2005) Political marketing or Political 'macheting'? A study of negative campaigning in Nigerian political discourse. In TRANS. Internet-ZeitschriftfürKulturwissenschaften.

[15] Patpong, P. (2009) Thai Persuasive Discourse: A Systemic Functional Approach to an Analysis of Amulet Advertisements. Revista Alicantina de Estudios Ingleses 22: 195-217.

[16] Rossiter, C. (1960) The American Presidency 2nd ed. New York: Harcourt Brace and World.

[17] Sigelman, L. (1996) Presidential Inaugurals: The Modernization of a Genre. Political Communication. 13: 81-92.

[18] Taiwo, R. (2007) Language, Ideology and Power Relations in Nigerian Newspaper Headlines. In Nebula. 4(1): 218-245

[19] Thompson, G. (2004) Introducing Functional Grammar. Beijing: Foreign Language Teaching and Research Press.

[20] Van Dikj, T. (2006) Politics, Ideology, and Discourse. Elsevier Ltd.

[21] Wardhaugh, R. (2006) An Introduction to Sociolinguistics. Oxford: Blackwell.

[22] Wang, Y. (2008) A Functional Study of the Evaluated Enhanced Theme Construction in English. Prentice Hall: Pearson Education South Asia Pte Ltd. 